2. Ильин Е. П. Психология для педагогов / Е. П. Ильин. - СПб. : Питер, 2012. - 640 с. 3. Психология профессионального педагогического мышления / под ред. М. М. Кашапова. - М. : Институт психологии РАН, 2003. - 398 с. 4. Санжиева Я. Б. Разработка и применение программы мониторинга профессионального развития учителя // Научные записки Забайкальского государственного университета. Серия: Профессиональное образование, теория и методика обучения. Выпуск № 6 (53) / 2013. Научная библиотека КиберЛенинка: - Режим доступа: http://cyberleninka.ru/article/n. 5. Сухомлинский В. А. Сто советов учителю / В. А. Сухомлинский. - К. : Рад. школа, 1984 - 254 с. - (Пед. б-ка).

\title{
ФОРМУВАННЯ ПРОФЕСІЙНОЇ МАЙСТЕРНОСТІ СТУДЕНТІВ ХУДОЖНЬО-ГРАФІЧНИХ ФАКУЛЬТЕТІВ
}

Кудренко Д. О. Формування професійної майстерності студентів художньографічних факультетів.

У статті 3'ясовано поняття «професійна майстерність» та «компетентність» студентів художньо-графічних факультетів у контексті образотворчої й декоративноприкладної діяльності. Визначено групи фахових умінь, які є обов'язковими для студентів художньо-графічних факультетів у здійсненні професійної діяльності.

Ключові слова: професійна майстерність, компетентність, професійні уміння, професійна діяльність, декоративно-прикладна діяльність.

Кудренко Д. А. Формирование профессионального мастерства студентов художественно-графических факультетов.

В статье раскрываются понятия «профессиональное мастерство» и «компетентность» студентов художественно-графических факультетов в контексте изобразительной и декоративно-прикладной деятельности. Определены группы профессиональных умений, которые являются обязательными для студентов художественно-графических факультетов в осуществлении профессиональной деятельности.

Ключевые слова: профессиональное мастерство, компетентность, профессиональные умения, профессиональная деятельность, декоративно-прикладная деятельность.

Kudrenko D. O. Forming professional skills of students at art-graphic departments.

The article reveals the concept of "professional skills" and "competence" of students at art-graphic departments in the context of the fine arts, decorative and applied activity. The author defines a set of professional skills that are compulsory for students of art-graphic departments in implementating professional activity.

Key words: professional skills, competence, professional abilities, professional activity, decorative and applied activity.

У Національній доктрині розвитку освіти в Україні у XXI столітті визначено головну мету, яка полягає у створенні умов для особистісного розвитку та творчої самореалізації кожного громадянина України, формуванні покоління, здатного навчатися впродовж усього життя, створювати та розвивати цінності громадянського суспільства; інтеграції України в європейський i світовий простір як 
конкурентоспроможної держави. Велику роль у розв'язанні цих завдань відіграє професійна підготовка студентів, яка $\epsilon$ передумовою успішної реалізації їхніх потенційних можливостей. Тому важливим завданням модернізації освіти $\epsilon$ підготовка професіоналів у всіх галузях науки, зокрема i в галузях художньографічного, дизайнерського спрямування. Професійна майстерність студентів охоплює багато аспектів, сукупність яких визначає сутність означеного поняття. Тому доцільно розглянути поняття «професійна майстерність учителя», зокрема вчителя образотворчого мистецтва, його складники.

У психолого-педагогічній літературі використовують арсенал понять задля оцінювання професійної майстерності вчителя. Педагог у професійній діяльності реалізує основні педагогічні завдання (навчання, виховання, розвиток підростаючого покоління), які залишаються незмінними щодо вимог, які висувають перед школою тієї чи іншої історичної епохи.

Так, наприклад, І. Песталоцці вважав, що вчитель мусить бути сповнений любові, мудрості, цінувати порядок, уміти володіти собою; учні повинні довіряти йому; він має бути здатним побачити в кожній дитині їі призначення. Й. Гербарт відзначав керівну роль учителя. Метою навчання вважав формування інтелектуальних умінь, уявлень, понять, теоретичних знань. А. Дістервег указував на те, що хороший учитель мусить не тільки володіти предметом, а й любити свою професію та дітей; уважав, що вчителю треба знати історію, літературу, а також весь час слідкувати за новими працями 3 педагогіки, психології й методики; надавав великого значення озброєнню вчителів практичними педагогічними вміннями й навичками. Л. Толстой уважав, що для педагогічної роботи велике значення має мистецтво й талант учителя [2, с. 6].

Як відомо, великий внесок у розвиток педагогічної науки зробили й українські науковці, а саме: Г. Сковорода вважав, що чуйність, гуманність та чесність можуть сформувати в молоді тільки такі педагоги, яким ці якості глибоко властиві. К. Ушинський доводить, що вчитель повинен бути не тільки викладачем того чи того предмета, але й вихователем; любити свою професію, ставитися 3 почуттям великої відповідальності до справи виховання, володіти педагогічною майстерністю й педагогічним тактом. Г. Ващенко бачив в особі вчителя насамперед носія ідеї українського національного виховання, здатного вкласти цю ідею в серця і розум молодого покоління. С. Русова вважала, що вчитель впливає на своїх учнів своїм характером, який неодмінно має бути веселим, енергійним. А. Макаренко відзначав, що справжній педагог-майстер повинен багато вміти і знати; надавав великого значення морально-політичному складу вихователя; визнавав, що якості особистості, характер педагога $є$ «інструментом» виховної роботи; підкреслював, що ніякі рецепти не допоможуть, якщо в самій особистості вихователя $\epsilon$ великі недоліки. В. Сухомлинський указував на виключне значення особистості вчителя у процесі виховання дітей, на необхідність досконалого глибокого знання свого предмета; вважав, що педагогічна майстерність залежить від бажання навчити, наснаги, готовності до подолання труднощів; основною вимогою до педагога вважав любов до дітей [2, с. 11].

Отже, питання, пов'язані з особистістю вчителя, його професійними якостями, знаннями, вміннями, навичками завжди були актуальними. Проте з розвитком суспільства, підвищенням ролі особистісного підходу, творчого чинника в навчанні та вихованні, змушують вносити корективи, висвітлюючи нові грані проблеми, розглядати їх із сучасних позицій, з урахуванням новітніх досягнень психології та педагогіки. 
Метою статmі є розкриття поняття професійної майстерності студентів художньо-графічних факультетів через такі терміни, як «професіоналізм», «майстерність», «компетентність»; а також визначення шляхів, що сприяють формуванню професійної майстерності.

Характеризуючи одну й ту ж проблему, означені педагогічні категорії вживаються в різних контекстах.

Розглядаючи поняття «професіоналізм», необхідно зазначити, що воно має кілька значень: перше - це заняття будь-чим як професією; друге - рівень майстерності; третє - оволодіння основами й глибинами будь-якої професії. У довідковій літературі професіоналізм визначається як «набута під час навчальної та практичної діяльності здатність до компетентного виконання трудових функцій; рівень майстерності та вправності у певному виді занять, відповідний рівню складності виконуваних завдань» [4, с. 361].

Слід зазначити, що в сучасній психолого-педагогічній літературі немає єдиного підходу щодо визначення окресленого поняття. Кожен із дослідників, який оперує цією категорією, виокремлює іiі домінуючий компонент чи співвідносить поняття «професіоналізм» $з$ близькоспорідненим, на його думку, поняттям. Так, дослідники пов'язують професіоналізм із самоосвітою (К. Левітан, Л. Мнацканян), уважають, що воно близьке до поняття «професійний потенціал» (І. Підласий), вбачають у ньому компонент соціальної зрілості педагога (В. Радул), розглядають професіоналізм як наявність знань і вмінь у вчителя (В. Синенко) [2, с. 24].

Водночас $\epsilon$ дві великі групи науковців, - представники однієї 3 яких співвідносять «професіоналізм» із поняттям «компетентність» (Н. Бордовська, О. Дубасенюк, І. Зязюн, А. Реан, О. Шиян та ін.), уважають його необхідним компонентом професіоналізму вчителя; друга група дослідників пов'язує поняття «професіоналізм» 3 поняттям «майстерність», ставлячи професіоналізм на більш високу сходинку в ієрархії педагогічних категорій (О. Анісимов, І. Багаєва, А. Деркач, Є. Ісаєв, С. Косорецький, В. Носкова, В. Слободчиков та ін.) [5, с. 26].

Так, І. Зязюн зазначає, що складниками професіоналізму $є$ компетентність i озброєність системою вмінь. Однак у педагогічній діяльності, на його думку, для професіоналізму мало лише цих компонентів. Необхідні певні особистісні якості, тому що сам педагог $\epsilon$ інструментом впливу на учня. I цей інструмент - його душа [4, с. 182].

Представники іншої позиції (Є. Ісаєв, С. Косорецький, В. Слободчиков) під поняттям «професіонал» розуміють сукупність понять «особистість» і «майстер». «Професіонал» розглядається як цілісний суб'єкт, вільний і відповідальний у проектуванні, здійсненні та творчому перетворенні власної діяльності. Цього погляду дотримується й І. Багаєва. Однак уточнює, що «професіоналізм» $є$ поняттям більш високого рівня, ніж «майстерність», оскільки останнє засноване на практичних прикладних уміннях педагога [2, с. 12].

По-різному інтерпретується поняття «майстерність». Наприклад, у словнику «Професійна освіта», майстерність витлумачено як «характеристику педагогічної діяльності високого рівня, де головною ознакою є бездоганне уміння навчати, формувати позитивні риси особистості й характеру майбутніх фахівців» [3, с. 235].

А. Макаренко вважав, що «педагогічна майстерність»- це знання особливостей педагогічного процесу, вміння його побудувати й привести в дію [4, с. 236].

Ця педагогічна категорія розглядається дслідниками 3 різних позицій: як компонент педагогічного мистецтва, педагогічної творчості (Н. Бордовська, Б. Лихачов, А. Реан); індивідуальний стиль діяльності вчителя, вияв свого «Я» в 
професії (В. Загвязинський, В. Радул); самореалізація особистості вчителя у педагогічній діяльності (І. Зязюн); найвищий рівень педагогічної діяльності (Н. Кузьміна, Н. Кухарев) [4, с. 244].

Науковці Н. Бордовська, І. Зязюн, Н. Коломинський, А. Реан, О. Шиян бачать у майстрі педагогічної праці насамперед висококомпетентного у психологопедагогічній і у власній предметній сфері спеціаліста, який уміє репродукувати у практичній діяльності на високому рівні професійні знання, навички та вміння, тобто вважають, що майстерність, так само, як і професіоналізм учителя, залежить від його компетентності [4; с. 168].

У сучасній психолого-педагогічній літературі 3 проблеми професійної компетентності вчителя $є$ різні погляди. Дослідники визначають компетентність як одну зі сходинок професіоналізму, тобто як систему знань, умінь, навичок, способів діяльності, психологічних якостей, необхідних вчителю для здійснення педагогічної діяльності [3; с. 185].

Отже, професійна майстерність викладача - це синтез властивостей, якостей його особистості, що надає змогу в межах здійснення своєї професійної діяльності протягом тривалого часу виконувати іiї впевнено, самостійно. Професійна майстерність у педагогічній діяльності не $\epsilon$ природженою, формується поступово, розвивається у процесі професійної діяльності, рівень їі можна змінити за допомогою свідомої, цілеспрямованої роботи [3, с. 188].

Для студентів художньо-графічних факультетів особливо важливим $\epsilon$ формування не лише педагогічних, психологічних знань, а й системи професійнопрактичних умінь та навичок, що $є$ невід'ємним складником професійної майстерності. До них належать художні або фахові вміння, оскільки здатність розкривати задум твору, його красу передбачає володіння педагогом як системою педагогічних, так і фаховими інтегративними знаннями та вміннями. Відповідно, можна виокремити групи вмінь, які $є$ обов'язковими для студентів художньографічних факультетів у здійсненні ними професійної діяльності, це:

- сприймально-оцінні - здатність особистості до естетичного оцінювання навколишнього світу, його краси та гармонії;

- $\quad$ зображувальні (графічні та живописні) - уміння відтворювати явища та предмети засобами живопису, рисунку, користуватися законами повітряної та лінійної перспективи, навички роботи з різноманітними матеріалами, використання різних технік тощо;

предметів, законів композиції.

конструктивні - знання закономірностей конструктивної побудови

Отже, для розвитку професійної майстерності майбутній учитель образотворчого мистецтва повинен оволодіти спеціальними, фаховими вміннями. Формування художніх умінь здійснюється на основі дисциплін образотворчого та декоративноприкладного спрямування. Характерною рисою цих дисциплін $\epsilon$ систематична самостійна робота студентів, спрямована на формування, розвиток і вдосконалення практичних навичок. Ефективність самостійної роботи студентів залежить від низки умов. Важливе значення має активність самих студентів, а також розуміння значення та важливості практичних вправ у їхній майбутній професійній діяльності. Треба зауважити, що вирішальною $\epsilon$ i роль викладача в організації i керівництві самостійною роботою студентів, яка повинна бути добре продуманою в методичному плані, щоб малювання не здійснювалося стихійно, бездумно, епізодично [6, с. 156].

Під час самостійної та практичної роботи студентам потрібно частіше практикуватися в розв'язанні творчих задач: малювання з натури, з уяви на різні теми; 
виконання начерків та зарисовок різноманітних об'єктів, предметів; створення сюжетних композицій на основі спостережень, творчої інтерпретації. Варто зазначити, що важливим чинником професіоналізму вчителя образотворчого мистецтва є здатність педагога до творчої уяви та фантазії, креативно мислити, вміння імпровізувати [5, с. 211].

Отже, професійна майстерність студентів художньо-графічних факультетів полягає в оволодінні ними не лише дисциплінами психолого-педагогічного циклу, але й знаннями, уміннями та навичками художньо-графічного та декоративноприкладного характеру. У педагогічній роботі студенти синтезують художньопрактичні та психолого-педагогічні знання та навички, що $є$ запорукою успішного здійснення їх професійної діяльності. Важливим специфічним складником професійної майстерності студентів художньо-графічних факультетів $є$ практичні уміння та навички. Джерелом їх формування $є$ самостійна практична діяльність студентів, яка виявляється у формі зарисовок, начерків, ескізування тощо. Систематизоване їх виконання сприяє розвитку творчих здібностей майбутнього вчителя образотворчого мистецтва, формуванню його особистості та зростанню професійної майстерності. Постійний самоконтроль, здійснюваний студентами, постановка відповідних завдань, послідовне оволодіння методами виконання практичних рисунків, допомагає оволодіти цим видом образотворчої діяльності.

\section{Література}

1. Бабанский Ю. К. Оптимизация процесса обучения / Ю. К. Бабанский. - М. : Педагогика, 1977. - 256 с. 2. Багаева И. Д. Профессионализм педагогической деятельности и основы его формирования у будущего учителя: автореф. дис. на соискание ученой степени д-ра. пед. наук: 14.00.14 / Багаева И. Д. - Л., 1991. - 36 с. 3. Гончаренко С. У. Професійна освіта: [навч. посіб.] / С. Гончаренко. - К. : Вища шк., 2000. - 380 с. 4. Зязюн І. А. Педагогічна майстерність / І. А. Зязюн. - К. : Вища шк., 1997. - 349 с. 5. Кардовский Д. Н. Об искусстве / Д. Н. Кардовский. - М. : Искусство, 1960. - 281 с. 6. Ростовцев Н. Н. Учебный рисунок: [учеб. пособ.] / Н. Н. Ростовцева. - М. : Просвещение, 1976. - 288 с.

УДК 378.147:[37.011. - 051]:62/64

Зоя Кучер

\section{ФОРМУВАННЯ ПРОФЕСІЙНО-ПЕДАГОГІЧНОЇ КОМПЕТЕНТНОСТІ МАЙБУТНЬОГО ВЧИТЕЛЯ ТЕХНОЛОГІЙ У МОДУЛЬНІЙ СИСТЕМІ НАВЧАННЯ}

Кучер 3. С. Формування професійно-педагогічної компетентності майбутнього вчителя технологій у модульній системі навчання.

У статті розкрито сутність поняття «професійно-педагогічна компетентність». Визначено принципи побудови професійно-орієнтованих модульних програм та умови їх реалізації в технологічній освіті. Особливу увагу звернено на процес неперервності вивчення спеціальних дисциплін швейного напрямку та використання проектних технологій.

Ключові слова: професійно-педагогічна компетентність, модульна програма, проектні технології, технологічна освіта.

Кучер 3. С. Формирование профессионально-педагогической компетентности будущего учителя технологий в модульной системе обучения.

В статье раскрыто сущность понятия «профессионально-педагогическая 